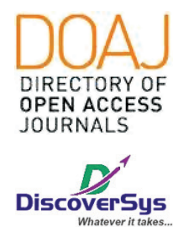

Published by DiscoverSys

\title{
Hubungan antara perubahan iklim dengan jumlah kasus demam dengue (DD) di Denpasar, Bali tahun 2010-2015
}

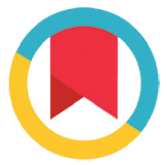

CrossMark

I Gusti Agung Bagus Arya Wiradarma, ${ }^{1 *}$ I Ketut Agus Somia ${ }^{2}$

\section{ABSTRACT}

Background: Dengue is one of tropical infectious disease that can give a serious public health problem in Denpasar. Several factors have been associated with the high prevalence of dengue fever; one of them is climate changes. This study aims to determine the relations between climate change and a number of dengue cases in Denpasar.

Methods: The climate change and a number of dengue cases data take place in Denpasar from the year 2010-2015 using observational study. The Spearman correlation test was used to know the relation between climate change (maximum and minimum temperature, rainfall, humidity, light duration, and wind velocity ) and a number of dengue cases. Data were analyzed using SPSS version 20 software for windows.
Results: The highest prevalence of Dengue Fever infection was in $4,431(38.16 \%)$ cases in 2010 , followed by $1,837(15,82 \%)$ cases in $2014,1,766$ (15.22\%) cases in 2013, 1,576 (13.57\%) cases in 2015, $1,009(8.69 \%)$ cases in 2012, and 992 (8.54\%) cases in 2011. Based on climate variables, rainfall has a weak significant relation affecting the number of dengue cases compared with others ( $r=0.247$; $p=0.036)$.

Conclusion: Rainfall was the only climates variables significantly related to the high prevalence of dengue fever in Denpasar, Bali since 2010-2015. So, further efforts need to be done to prevent dengue cases on rainy season.

Keywords: Climate Change, Correlation, Dengue Fever, Denpasar

Cite This Article: Wiradarma, I.G.A.B.A., Somia, I.K.A. 2019. Hubungan antara perubahan iklim dengan jumlah kasus demam dengue (DD) di Denpasar, Bali tahun 2010-2015. Intisari Sains Medis 10(3): 473-476. D0I: 10.15562/ism.v10i3.423

\section{ABSTRAK}

Latar Belakang: Demam berdarah adalah salah satu penyakit menular tropis yang dapat menimbulkan masalah kesehatan masyarakat yang serius di Denpasar. Beberapa faktor telah dikaitkan dengan tingginya prevalensi demam berdarah, salah satunya adalah perubahan iklim. Penelitian ini bertujuan untuk mengetahui hubungan antara perubahan iklim dan jumlah kasus demam berdarah di Denpasar.

Metode: Perubahan iklim dan jumlah data kasus demam berdarah terjadi di Denpasar dari tahun 2010-2015 menggunakan studi observasional. Korelasi Spearman digunakan untuk mengetahui hubungan antara perubahan iklim (suhu maksimum dan minimum, curah hujan, kelembaban, durasi cahaya dan kecepatan angin) dan jumlah kasus demam berdarah. Data dianalisis menggunakan perangkat lunak SPSS versi 20 untuk windows.
Hasil: Prevalensi tertinggi infeksi Demam Berdarah adalah pada 4.431 (38,16\%) kasus pada tahun 2010, diikuti oleh 1.837 (15,82\%) kasus pada tahun 2014, $1.766(15,22 \%)$ kasus pada tahun 2013, 1.576 $(13,57 \%)$ kasus pada tahun 2015, 1.009 (8,69\%) kasus pada 2012, dan 992 (8,54\%) kasus pada 2011. Berdasarkan variabel iklim, curah hujan memiliki hubungan signifikan yang lemah dalam mempengaruhi jumlah kasus demam berdarah dibandingkan dengan yang lain $(r=0,247 ; p=0,036)$.

Kesimpulan: Curah hujan adalah satu-satunya variabel iklim secara bermakna terkait dengan prevalensi tinggi demam berdarah di Denpasar, Bali sejak 2010-2015. Oleh karena itu, upaya lebih lanjut perlu dilakukan untuk mencegah kasus demam berdarah pada musim hujan.
Fakultas Kedokteran Universitas Udayana, Bali, Indonesia

${ }^{2}$ Bagian IImu Penyakit Dalam, Fakultas Kedokteran Universitas Udayana, RSUP Sanglah, Bali, Indonesia

*Korespondensi: I Gusti Agung Bagus Arya Wiradarma; Program Studi Pendidikan Dokter Fakultas Kedokteran Universitas Udayana, Bali, Indonesia; aryawiradarma@yahoo.co.id

Diterima: 04-03-2019

Disetujui: 16-08-2019

Diterbitkan: 01-12-2019
Kata kunci: Perubahan Iklim, Korelasi, Demam Berdarah, Denpasar

Cite Pasal Ini: Wiradarma, I.G.A.B.A., Somia, I.K.A. 2019. Hubungan antara perubahan iklim dengan jumlah kasus demam dengue (DD) di Denpasar, Bali tahun 2010-2015. Intisari Sains Medis 10(3): 473-476. D0I: 10.15562/ism.v10i3.423

\section{PENDAHULUAN}

Dengue merupakan salah satu virus anthropod yang bisa menyerang manusia. ${ }^{6}$ Virus dengue termasuk dalam keluarga Flaviviridae. ${ }^{1}$ Virus ini masih belum ada obatnya ataupun antiviralnya. ${ }^{1}$ Virus dengue ditularkan melalui nyamuk Aedes didunia sekitar 400 juta kasus/tahun. ${ }^{3}$ Kasus demam berdarah terutama terjadi di daearah yang hanya memiliki 2 musim atau disebut juga negara negara dengan iklim tropis. Virus dengue memiliki aegypti. ${ }^{1}$ Beberapa analisa mengindikasikan bahwa 
4 jenis serotype yaitu, DV-1, DV-2, DV-3, DV-4. Semua serotype tersebut bisa menyebabkan demam dengue atau pun demam berdarah dengue. ${ }^{2}$

Dari data yang didapat di negara Filipina, tepatnya di Kota Iligan, di tahun 2005 angka tertinggi untuk kasus demam dengue yaitu 547 dan kasus demam berdarah dengue sebanyak 399 kasus. ${ }^{1}$ Angka terendah ditemukan tahun 2008, untuk kasus demam dengue sebanyak 128 kasus dan demam berdarah dengue sebanyak 87 kasus. $^{1}$ Sedangkan data yang didapat dari Indonesia, tepatnya di daerah Nganjuk, Provinsi Jawa Timur, menunjukkan insiden rate nya adalah 4.05 per 100.000 penduduk dari tahun 2005 sampai tahun 2010. Angka insiden demam berdarah dengue (26.53 per 100.000 penduduk) ditemukan pada bulan Februari tahun 2007 dan angka insiden terendah ditemukan pada bulan September $2006 .{ }^{8}$

Perubahan iklim merupakan salah satu faktor mempengaruhi jumlah kasus dengue. ${ }^{9}$ Dari data yang didapat di Kota Iligan dan di daerah Nganjuk, kasus demam berdarah dengue dan kasus demam berdarah dengue dipengaruhi oleh perubahan iklim, diantaranya adalah temperatur maksimum, temperatur minimum, curah hujan, kelembapan relatif, durasi cahaya, kecepatan cahaya. ${ }^{1,8}$ Temperatur maksimum dan temperatur minimum dapat mempengaruhi perkembangan nyamuk karena mempengaruhi kesuburan nyamuk, memperpanjang umur nyamuk dewasa, mempengaruhi frekuensi gigitan nyamuk, memperpendek periode inkubasi patogen, mempengaruhi siklus gonotropik, kemudian mampu mempengaruhi waktu nyamuk muncul ke permukaan untuk mendapatkan makanan pertamanya. Pada suhu $<20^{\circ} \mathrm{C}$ maka proses fertilisasi pada nyamuk akan menurun dan pada suhu $<15^{\circ} \mathrm{C}$ akstivitas makan nyamuk dapat dibatasi. ${ }^{3,8}$ Kelembapan dan curah hujan juga dapat dapat mempengaruhi jumlah kasus demam dengue dan demam berdarah dengue karena dapat mempengaruhi masa hidup nyamuk dan mampu mempengaruhi potensi nyamuk untuk menularkan virus dengue. ${ }^{1,8}$ Kemudian hujan bisa menjadi sarang yang bagus bagi nyamuk untuk berkembang biak. ${ }^{8}$ Kelembapan relatif juga dapat mempengaruhi perilaku makan, proses penempatan telur nyamuk dan mempercepat replikasi virus dengue. ${ }^{8}$ Durasi cahaya dapat mempengaruhi jumlah kasus demam berdarah dengue dan demam berdarah dengue karena nyamuk dapat berkembang dari telur hingga nyamuk dewasa pada keadaan yang benar - benar gelap. ${ }^{8}$ Sedangkan jika durasi cahaya yang lama akan mampu menurunkan angka insiden rate demam dengue dan demam berdarah dengue. ${ }^{8}$ Terakhir adalah kecepatan angin mampu mempengaruhi kasus demam dengue dan demam berdarah dengue karena jika angin didaerah tersebut tenang dan kecepatan anginnya lambat maka jangkauan nyamuk akan semakin jauh, jika jangkauan nyamuk semkain jauh maka penularan virus dengue juga akan semakin luas. ${ }^{8}$

Berdasarkan beberapa hal yang telah dipaparkan di atas, maka studi ini bertujuan untuk mencari tahu hubungan antara berbagai faktor perubahan iklim seperti temperatur, kelembapan, hujan, cahaya, dan angina terhadap angka prevalensi demam dengue di Denpasar, Bali sejak tahun 2010-2015.

\section{METODE}

Penelitian ini sudah mendapatkan izin ethical clearance dari pihak Fakultas Kedokteran Unud dan sudah mendapat izin dari pihak Badan Meteorologi Dan Geofisika (BMKG) untuk melakukan penelitian ini. Jenis penelitian ini adalah analytic observational dengan menggunakan desain penelitian cross sectional. Penelitian ini dilakukan di Denpasar pada tahun 2016. Data yang dimaksudkan adalah seluruh pasien demam dengue yang terekam sejak tahun 2010 - 2015 yang didapat dari Dinas Kesehatan Provinsi Bali dan data iklim didapat dari Badan Meteorologi Dan Geofisika (BMKG) Provinsi Bali. Informasi tentang iklim terbagi atas beberapa variable yakni temperature/suhu (minimum dan maksimum), kelembapan, hujan, cahaya, dan angina. Setelah semua data yang diperlukan sudah diperoleh maka data akan diproses di SPSS versi 20 kemudian dianalisis dengan analisis bivariat, yaitu korelasi koefisien spearman. Nilai P kurang dari 0,05 dikatakan bermakna secara statistik.

\section{HASIL}

Berdasarkan analisis jumlah kasus diketahui bahwa demam dengue terendah terjadi pada tahun 2011 yaitu 992 (8,54\%) kasus sedangkan jumlah tertinggi terjadi pada tahun 2010 yaitu 4.431 (38,16\%) kasus di Denpasar. Jumlah kasus dapat dilihat pada Tabel 1 berikut.

Hasil penelitian menunjukkan bahwa temperature maksimum di kota Denpasar adalah sekitar $32^{\circ} \mathrm{C}$ sedangkan suhu minimum adalah $24^{\circ} \mathrm{C}$. Angka kelembapan di daerah Denpasar pun beragam namum rata-rata dketahui sebesar $79 \%$. Sedangkan total curah hujan di Denpasar dalam setahun juga diperoleh sebesag $1.747,9 \mathrm{~mm}$, diikuti dengan $71 \%$ intensitas cahaya dan sebesar 6 knots rata-rata kecepatan angina di Denpasar.

Korelasi antara perubahan iklim dengan jumlah kasus dengue di Denpasar yang berhubungan signifikan hanya curah hujan saja dengan hasil 
Tabel 1 Jumlah kasus demam dengue di Denpasar dari tahun $2010-2015$

\begin{tabular}{lcc}
\hline Tahun & Jumlah kasus dengue (N=11.611) & Persentase (\%) \\
\hline 2010 & 4431 & 38,16 \\
2011 & 992 & 8,54 \\
2012 & 1009 & 8,69 \\
2013 & 1766 & 15,22 \\
2014 & 1837 & 15,82 \\
2015 & 1576 & 13,57 \\
\hline
\end{tabular}

Tabel 2 Korelasi antara variabel iklim dan kasus dengue di Denpasar pada tahun 2010 - 2015

\begin{tabular}{lccc}
\hline Variabel Iklim & Rata-Rata & $\mathbf{r}$ & $\mathbf{p}$ \\
\hline Temperatur maksimum $\left({ }^{\circ} \mathrm{C}\right)$ & 32 & 0,185 & 0,120 \\
Temperatur Minimum $\left({ }^{\circ} \mathrm{C}\right)$ & 24 & 0,149 & 0,212 \\
Kelembapan $(\%)$ & 79 & 0,194 & 0,102 \\
Total Curah Hujan (mm) & $1.747,9$ & 0,247 & $0,036^{*}$ \\
Cahaya (\%) & 71 & $-0,106$ & 0,374 \\
Angin (knots) & 6 & $-0,167$ & 0,160 \\
\hline
\end{tabular}

r: Korelasi Spearman; Nilai P $<0,05$ dikatakan berbeda bermakna secara statistik.
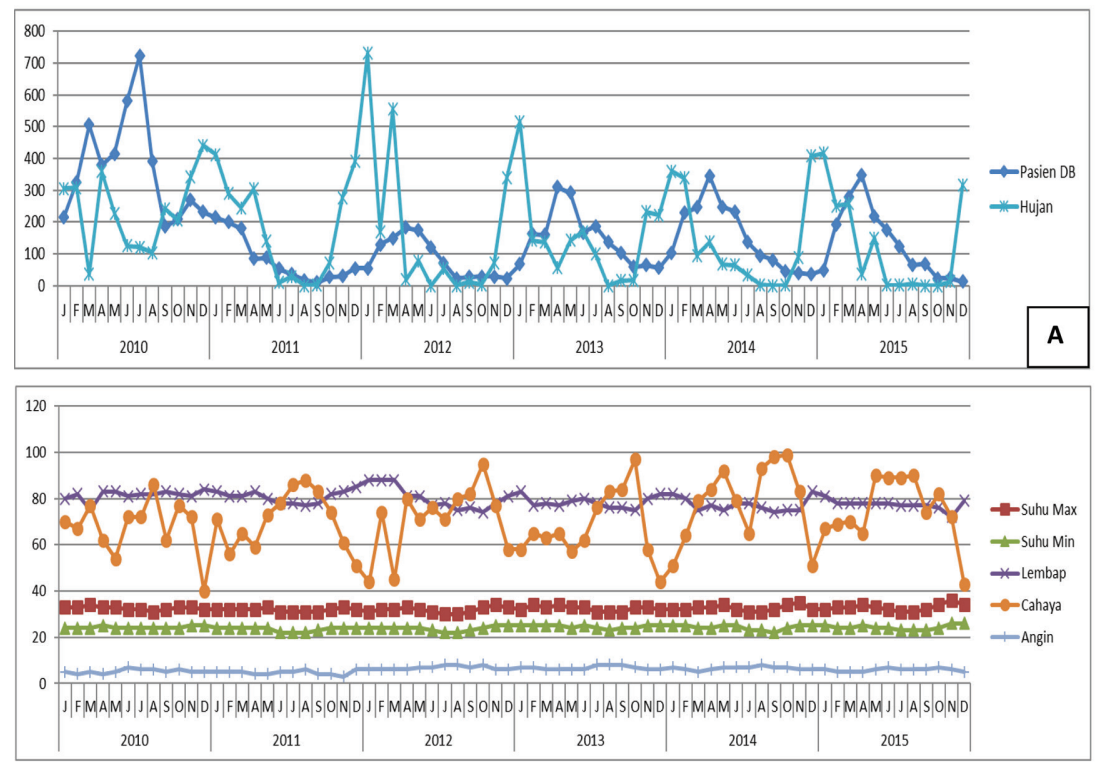

Gambar 1 Curah hujan (A) maupun variabel iklim (B) terhadap jumlah kasus demam dengue di Denpasar tahun 2010 - 2015

0.247 menggunakan metode Korelasi Spearman. Sedangkan nilai-p menunjukkan angka 0.036 yang artinya nilai $\mathrm{p}<0.05$. Dari hasil tersebut kita bisa menyimpulkan bahwa yang berkorelasi signifikan terhadap jumlah kasus dengue adalah curah hujan di Denpasar dari tahun 2010 sampai 2015. Sedangkan variabel iklim lainnya tidak signifikan. Temperatur maksimum dan temperatur minimum menunjukkan angka 0.120 dan 0.212. Kelembapan relatif menunjukkan angka 0.102 . Durasi cahaya menunjukkan angka 0.374. Sedangkan hasil kecepatan angin menunjukkan angka 0.160. Semua hasil data yang sudah di analisis di SPSS dapat dilihat di Tabel 2 dan Gambar 1.

\section{PEMBAHASAN}

Curah hujan berkorelasi signifikan sesuai dengan penelitian yang dilakukan oleh Gama dan Nakagoshi. ${ }^{8}$ Variabel curah hujan ini dapat mempengaruhi jumlah kasus dengue karena hujan dapat memberikan sarang bagi nyamuk ditempat tempat seperti kaleng bekas, kubangan, dan plastik yang sudah terisi air hujan. Dari data Gambar 1 menunjukkan bahwa dari bulan Desember hingga Februari terjadi peningkatan jumlah kasus dengue di Denpasar. Itu terjadi karena pada bulan Desember hingga Februari masih dalam musim hujan.Seperti hasil pada Tabel 1 bisa kita lihat bahwa temperatur maksimum dan temperatur minimum tidak berkorelasi signifikan. Rata - rata suhu temperatur maksimum dan temperatur minimum adalah $24-32^{\circ} \mathrm{C}$ dari tahun 2010 sampai 2015. Hasil yang diperoleh tersebut sama dengan penelitian sebelumnya yang dilakukan oleh Yu dkk. ${ }^{7}$ Menurut penelitian Gama dan Nakagoshi suhu lingkungan yang dibutuhkan nyamuk untuk tumbuh dan berkembang biak secara optimal adalah $25-27^{\circ} \mathrm{C} .{ }^{8}$ Kelembapan relatif juga tidak menunjukkan korelasi yang signifikan dengan kasus demam dengue di Denpasar. Dari Gambar 1 bisa dilihat bahwa gambaran kelembapan terlihat cukup stagnan. Sedangkan menurut penelitian Malavige dan Bhatia Rajesh, nyamuk adalah spesies yang menyukai kelembapan untuk beradaptasi dan kelembapan yang sering berubah - ubah bisa mempengaruhi jumlah kasus dengue karena bisa mempercepat replikasi virus dengue. ${ }^{5,10}$ Durasi cahaya juga tidak memiliki korelasi yang signifikan pada kasus dengue di Denpasar. Durasi cahaya di Denpasar cenderung lama, dari Gambar 1 bisa dilihat bahwa pada bulan Oktober - Februari adalah diatas angka 50 dan rata - rata adalah $71 \%$. Sedangkan menurut penelitian Gama dan Nakagoshi di Nganjuk menunjukkan durasi cahaya yang rendah. Terakhir kecepatan angin juga tidak menunjukkan korelasi signifikan. ${ }^{8}$ Menurut Gubbler, kecepatan angin secara tidak langsung mempengaruhi air dan temperatur udara juga menyebarkan nyamuk secara pasif. ${ }^{4}$ Tetapi, temperatur di Denpasar adalah $24-32^{\circ} \mathrm{C}$, sehingga hal tersebut bisa menggangu perkembangan nyamuk.

\section{SIMPULAN}

Simpulan yang bisa diambil dari penelitian ini adalah bahwa curah hujan berkolerasi signifikan 
rendah dengan jumlah kasus dengue di Denpasar dari tahun 2010 sampai tahun 2015. Kemudian variabel iklim seperti temperatur maksimum, temperatur minimum, kelembapan relatif, durasi cahaya, dan kecepatan angin tidak berkorelasi signifikan kepada jumlah kasus dengue di Denpasar dari tahun 2010 sampai 2015.

\section{ETIKA PENELITIAN}

Penelitian ini telah mendapat persetujuan etik dari komite Etik Fakultas Kedokteran Universitas Udayana, Bali, Indonesia sebelum penelitian berjalan.

\section{KONFLIK KEPENTINGAN}

Penulis menyatakan bahwa tidak terdapat konflik kepentingan dalam penulisan artikel ini.

\section{PENDANAAN}

Penulis bertanggung jawab penuh terhadap pendanaan penelitian ini tanpa melibatkan sponsor, grant, ataupun sumber pendanaan lainnya.

\section{KONTRIBUSI PENULIS}

Seluruh penulis berkontribusi bersama-sama dalam penyusunan artikel ini dari tahap usulan proposal, pengambilan data, analisis data, hingga interpretasi data penelitian.

\section{DAFTAR PUSTAKA}

1. Dulay AVS, Bautista JR, Teves FG. Climate Change and Incidence of Dengue Fever (DF) and Dengue Hemorrhagic Fever (DHF) in Iligan City, Lanao del Porte, Philippines. Internasional Research Journal of Biological Sciences. 2013;2(7):37-41.

2. Bandyopadhyay B, Bhattacharyya I, Adhikary S, Konar J, Dawar N, Sarkar J et al. A Comprehensive Study on The 2012 Dengue Fever Outbreak in Kolkata, India. ISRN Virology. 2013:ID 207580

3. Morin CW, Comrie AC, Ernst K. Climate and dengue transmission: evidence and implications. Environ Health Perspect. 2013;121(11-12):1264-72.

4. Gubbler DJ. Dengue and Dengue Hemorrhagic fever. Clin Microbiol Rev. 1998;11(3):480-96.

5. Malavige GN, Fernando S, Fernando DI, Seneviratne SL. Dengue viral infections. Postgrad Med J. 2004;80(948):588-601.

6. Guzman MG, Halstead SB, Artsob H, Buchy P, Farrar J, Gubler DJ, et al. Dengue: a continuing global threat. Nat Rev Microbiol. 2010;8(12 Suppl):S7-16.

7. Yu HL, Yang SJ, Yen HJ, Christakos G. A Spatio-Temporal Climate-Based Model of Early Dengue Fever Warning in Southern Taiwan. Stoch Environ Res Risk Assess. 2011;25(4):485-494.

8. Gama ZP, Nakagoshi N. Climatic Variability and Dengue Haemaorrahgic Fever Incidence in Nganjuk District, East Java, Indonesia. Acta Biologica Malaysiana. 2013;2(1):31-39.

9. Paul B, Tham WL. Interrelation Between Climate Change and Dengue in Malaysia. Health. 2015;7:672-678.

10. Bhatia R, Dash AP, Sunyoto T. Changing epidemiology of dengue in South-East Asia. WHO South East Asia J Public Health. 2013;2(1):23-27.

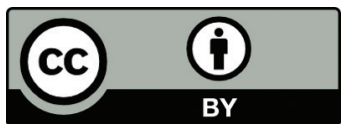

This work is licensed under a Creative Commons Attribution 